Vol. 30, julho 2014, http://dx.doi.org/10.5380/dma.v30i0.34221

\begin{tabular}{l|l}
\hline SISTEMA \\
ELETRONICO \\
DE REVISTAS \\
SER I UFPR
\end{tabular}

\title{
Developing Renewable Energy: Comparative Scenarios and Public Policy Perspectives from some Latin American Countries
}

\section{Desenvolvimento de energias renováveis: comparativo dos cenários e das perspectivas de políticas públicas para alguns países da América Latina}

\begin{abstract}
Claudia Cecilia LARDIZABAL ${ }^{1}$, Ismene ROSALES ${ }^{2}$, Janaina Camile PASQUAL ${ }^{3}$, Gricelda HERRERA ${ }^{4}$, Sandra MEJIA ${ }^{5}$, Mariel Álvarez CANCINO ${ }^{6}$

${ }^{1}$ Master in Integrated Watershed Management (CATIE). National Autonomous University of Honduras. E-mail: claudia_lardizabal@unah.edu.hn

${ }^{2}$ Doctorate in Hydraulic Engineering (UNAM). Universidad Autónoma Metropolitana, Mexico. E-mail: america_rosales@axtel.net

${ }^{3}$ Master in Multipurpose Technical Cadastre and Land Management (UFSC). Centro Internacional de Hidroinformática (ITAIPU Binacional). E-mail: janainapas@yahoo.com.br

${ }^{4}$ Master in Economy and Territorial Development (Universidad de Huelva). Centro de Investigaciones y Proyectos Aplicados a las Ciencias de la Tierra (CIPAT) Escuela Superior Politécnica del Litoral (ESPOL). E-mail: griceldaherrer@gmail.com

${ }^{5}$ Master in Food Security and Nutrition (UCA). Delegacion Union Europea, Nicaragua. E-mail: Sandra.MEJIA@eeas.europa.eu

${ }^{6}$ Renewable Resources Engineering at the University of Chile. Corporación Regional de Desarrollo Productivo, Chile. E-mail: alvarezc.mariel@, gmail.com
\end{abstract}

Article: Received in: November 5 2013; Final version accepted in: April 182014.

ABSTRACT The energy matrix of Latin American and the Caribbean countries has one of the largest renewable energy components when compared to other regions of the world. Nonetheless, by 2009 nearly three-quarters of its structure corresponded to fossil fuels, with most of the countries being net importers of these fuels. This situation marks the region's dependence on the effects of changes in energy commodities. Therefore, the opportunity lies in higher use of renewable energy sources that contribute to the country's energy security and represent significant environmental benefits. The purpose of this paper is to provide a comparative analysis of current energy scenarios of six Latin American countries (Mexico, Honduras, Nicaragua, Brazil, Ecuador and Chile) in order to evaluate the policies, programs and strategies implemented in the search for greater participation of renewable energy. Considering the importance of the water-energy nexus that could serve to promote renewables under conditions of water scarcity, a qualitative data comparison was accomplished, considering energy consumption, $\mathrm{CO}_{2}$ emissions, GDP and water withdrawals per country. The authors conclude that, despite technological and financial constraints, all the involved countries are moving towards the substitution of a fossil fuel based matrix to a renewable one. This process could be seen as a result of clear policies and 
strategies that have been set, which include (but are not limited to) price regulations setting, preferential prices to electricity generated through renewable energy technologies and incentives formulated to encourage the production of biofuels.

Keywords: water and energy nexus; renewable energy; public policy.

RESUMO A matriz energética dos países da América Latina e Caribe tem um dos maiores índices de energias renováveis, quando comparada à de outras regiões do mundo. No entanto, até 2009, cerca de três quartos de sua estrutura correspondia a combustíveis fósseis, com a maioria dos países sendo importadores líquidos destes combustíveis. Esta situação marca a dependência da região dos efeitos das mudanças nas commodities energéticas. Sendo assim, a oportunidade está no maior uso de fontes renováveis de energia, que contribuem para a segurança energética do país e representam benefícios ambientais significativos. O objetivo deste trabalho é fornecer uma análise comparativa dos cenários energéticos atuais de seis países da América Latina (México, Honduras, Nicarágua, Brasil, Equador e Chile), a fim de avaliar as políticas, os programas e as estratégias implementadas na busca da maior participação das energias renováveis. Considerando a importância do nexo água-energia, realizou-se uma comparação de dados qualitativos, considerando o consumo de energia, emissões de $\mathrm{CO}_{2}$, PIB e retiradas de água por país. Os autores concluíram que, apesar das limitações tecnológicas e financeiras, todos os países envolvidos estão se movendo para a transformação de uma matriz baseada em combustíveis fósseis para uma matriz com bases renováveis. Este processo pode ser visto como resultado de políticas claras e estratégias que foram definidas, que incluem (mas não estão limitadas) a definição de regras de preços, preços preferenciais para a eletricidade gerada por meio de tecnologias de energia renovável e incentivos formulados para incentivar a produção de biocombustíveis.

Palavras-chave: nexo água-energia; energias renováveis; políticas públicas.

\section{Introduction}

Our planet faces severe social, political, economic and environmental crises that require a profound change in direction. Indeed, human-induced global warming, the generation of toxic waste, deforestation, harm to human health, and geopolitical problems resulting from the depletion of easy-to-access fossil fuel ${ }^{1}$ resources are threats that endanger the welfare of the earth and its inhabitants.

One issue that deserves immediate attention is the current global energy matrix, which is characterized by a total dependence on fossil fuels. Besides discussing for how long coal, gas and oil reserves will exist, we are required to significantly reduce the burning of fossil fuels to avoid accelerating climate change, which would have catastrophic consequences. Thus, it is not an option but an ethical responsibility to seek an alternative energy path.
On a global level, approximately $90 \%$ of the energy consumed comes from nonrenewable fossil resources, whose depletion is constantly higher, which is why the countries of the world are seeking alternative energy sources $^{2}$ (International Energy Agency, 2012). It should be noted that population growth, as well as economic development, generate a higher energy demand. According to Leff (2013) "the environmental crisis expresses the limits to growth, the unsustainability of economic rationality and technological reason".

The energy matrix of Latin American and the Caribbean countries has one of the largest renewable components if compared to other regions of the world, but even so in 2009 nearly three-quarters of its structure corresponded to fossil fuels (OLADE, 2011). Moreover, while there is a significant regional availability of oil, coal and gas resources, these are concentrated in few countries being net importers of most of these sources.

${ }^{1}$ Fossil fuel refers to carbon, oil, petroleum and natural gas (International Energy Agency, 2013).

${ }^{2}$ The world total primary energy supply in 2010 was composed by: $32,4 \%$ oil, $27,3 \%$ coal/peat, $21,4 \%$ natural gas, $5,7 \%$ nuclear, biofuels and waste $10 \%$, hydro $2,3 \%$ and other $0,9 \%$. 
Other countries currently can feed themselves and eventually export some surplus of oil, face medium-term depletion of their reserves due to high growth rates of their economies and energy demand.

This scenario undoubtedly marks the region's vulnerability to the effects of changes in international prices of energy commodities, which may occur as it has happened sometimes in severe economic crises. The opportunity is in the use of renewable energies that contribute to improve the environment and help mitigate, as much as possible, climate change and its collateral effects. As it will be discussed below, it is important to have an efficient regulatory framework that allows an adequate performance of the renewable energy market, as well as to promote the development of technologies that generate the best possible economic and social benefit for a country. According to Machado, Vilani and Chame (2012) "the loss of environmental quality and the reduction of the stock of natural resources require a new direction on the agenda of topics and issues to be discussed and institutionalized through the development and / or improvement of public policies".

Despite the fact that the analysis of public policies and renewable energy scenarios has been previously studied by other authors for several countries of the world, Arnette (2011), Devine (2005), Moosavian (2013), Yamussa II (2013), an assessment of Latin American countries has yet to be done. Considering these issues, this paper attempts to fill this gap and describe the renewable energy scenarios and public policies of six Latin American countries (Mexico, Honduras, Nicaragua, Brazil,
Ecuador and Chile). These countries were not chosen randomly; instead it was the result of a joint development study that began in a training held in La Serena (Chile) in June 2013, titled Adaptive Water-Energy Management in the Arid Americas. ${ }^{3}$ The authors, one from each country, studied the scenario of their respective country and contributed to this comparative study.

In section 2, the paper presents the renewable energy scenarios for each country through consistent data and brief analyses. ${ }^{4}$ In section 3 , comparative data of these countries will be presented, including fuel fossil energy consumption, alternative and nuclear energy consumption and carbon dioxide emissions, the world average for $2010^{5}$, as well as Gross Domestic Product (GDP) of these countries and annual freshwater withdraws, considering that water and energy are intricately linked.

Subsequently, section 4 will consider comparative perspectives with an explicit focus on public policy questions and section, considering that a diversified energy matrix based on renewable energy sources that operate in a decentralized manner could provide better energy security, reduced vulnerability of the system and greater environmental benefits in the countries studied. Section 5 concludes by synthesizing the findings derived from individual countries, and presenting a preliminary prognosis for Latin America.

Thus, a synthetic and comparative view allows us to derive some generic lessons for countries not included in the study and for regions other than Latin America. There are actions and strategies (Sustainable Light Program in Mexico, Chile's National Energy Strategy, Good

\footnotetext{
${ }^{3}$ The training involved advanced conceptual and practical training by international experts in the use and adoption of tools to address linkages between water resources and conventional and non-conventional energy, and interdisciplinary physical and social science approaches to water and energy joint management. The objective is to strengthen water and energy security through joint management in the context of adaption to global change in the Arid Americas (AQUASEC, 2013).

${ }^{4}$ Despite the dilemma in scientific circles about its classification, for this study hydroelectricity will be considered a renewable energy resource According to Environmental Protection Agency of USA (EPA, 2013). Hydroelectricity is considered renewable because it uses the Earth's water cycle to generate electricity. "Although hydropower has no air quality impacts, construction and operation of hydropower dams can significantly affect natural river systems as well as fish and wildlife populations”. Furthermore, hydropower's air emissions are negligible because no fuels are burned, unlike plants powered by gas, coal or oil.

${ }^{5}$ The primary greenhouse gases in the Earth's atmosphere are carbon dioxide $\left(\mathrm{CO}_{2}\right)$, methane $\left(\mathrm{CH}_{4}\right)$, Nitrous oxide $\left(\mathrm{NO}_{2}\right)$ and Fluorinated gases . According to OLADE (2011), the most widely used method of emissions inventory is the Method of Reference, which applies only to estimate carbon dioxide emissions, quantified at an aggregate level. $\mathrm{CO}_{2}$ emissions from combustion of fossil fuels, unlike other greenhouse gases, can be calculated from an acceptable degree of accuracy from the calculation of the amounts of carbon in the fuel, while the volume of the remaining emissions depends on technologies and combustion conditions. In short, $\mathrm{CO}_{2}$ emissions are directly linked to a country's energy matrix.
} 
Living Plan in Ecuador, PROINFA in Brazil, Nicaragua's Generation Expansion Indicative Plan and the Honduran Nation Plan) to diminish the use of petroleum and the promotion of renewable energy.

\section{Renewable energy scenario in some Latin American countries}

\subsection{North America}

\section{a. México}

The energy sector in Mexico is a key factor that influences the economical, productive and social development of the country; therefore it is of extreme importance for the Mexican economy. For the year 2010 in Mexico $88,8 \%$ of its energy derived from fossil fuels, $6,7 \%$ from renewable resources such as hydro, geothermal, solar, wind and biogas, and only 3,8\% from biomass (Sistema De Informacion Energetica, 2013).

The Mexican economy is highly dependent on petroleum production. However, the extraction of petroleum is diminishing and nowadays there are great difficulties to keep constant supply, which is why strategies for diversifying the ways energy can be obtained are being planned. In Mexico the participation of renewable energy represents only a low percentage, and observing the current development of clean energy production, a slightly significant short-term growth projection is expected (Domínguez, 2011). However, a strategy for a cleaner energy matrix has come in effect through different policies and programs that incentivize low energy consumption by the population, disposable of high-energy consumption equipment, energy saver light bulbs, among others.

According to the Secretariat of Energy (Mexico), by 2010 the installed wind power capacity was 500 megawatt (MW) between public and private projects, and it is expected that at least $4 \%$ of Mexico's installed electrical capacity will be mostly wind (MEXICO, 2011). Furthermore, the wind power national energetic potential is around $71,000 \mathrm{MW}$ considering only $10 \%$ of the total potential area (MEXICO, 2011). Additional initiatives, such as the Programa Luz Sustentable (Sustainable Light
Program) in Mexico, have helped reducing the emission of Greenhouse gases in approximately 2,8 million tons a year.

\subsection{Central America}

\section{a. Honduras}

The Honduran energy matrix has experienced constant changes in the past decades. In 1980, for example, the Francisco Morazán "El Cajon” dam was built and provided $100 \%$ of residential and $69 \%$ of total energy required by the country. However, due to an $8 \%$ annual energy demand increase, a prolonged drought and technical construction flaws, the energy matrix changed (FAO, 1996). Currently, Honduras is highly dependent on hydrocarbons for energy generation with exception of Guatemala and Belize. Besides that, Honduras is a net importer of petroleum fuels, mainly from the U.S. $(48,8 \%)$, Ecuador $(13,1 \%)$ and Venezuela $(13,1 \%)$ (CEPAL, 2008). Central America has not confirmed petroleum reserves, which makes it highly dependent on foreign energy sources (CEPAL, 2009).

Honduras relies heavily on fossil fuels, with $62 \%$ of the nation's energy production coming from non-renewable sources, primarily, thermo-based power systems, which are vulnerable to high and volatile international oil prices. The remaining 38\% comes from renewable energy, $34 \%$ of which is hydropower (OLADE, 2011). A strategy for the improvement of the energy matrix has come to effect through public policies that promote fiscal, financial and market incentives for renewable energy production, as well as reducing legal requirements for renewable energy projects among others. This is a positive step forward as it is important to mention that Honduras is the biggest generator of greenhouse gasses in Central America due to its electrical energy sub sector and its high dependence of thermal energy (Flores, 2010).

Honduras is now showing a boom in renewable energy projects. Some examples are: the wind farm built in the outskirts of Tegucigalpa, which generates $102 \mathrm{MW}$; a solar power project using photovoltaic technology in Choluteca promoted by the group of coastal communities (NASMAR) and the Spanish Cooperation Agency (AECID). This project is located in 
the communities of San Jose de la Landa y Montecillo, covering 151 hectares; it is currently under construction and will produce $15 \%$ of the entire state energy demand (Suelo Solar, 2013). Other photovoltaic projects are currently generating $3,000 \mathrm{kWh}$ a month (Alvarenga, 2013), as well as the "Aguan Electric Complex" located in El Aguan watershed (Casallas, 2012), comprising of Hydroelectric, Biomass and Photovoltaic generation. These projects will help to change the energy matrix and make it more sustainable (ENEEb, s.f). Additionally sugar plants are now supplying approximately $130 \mathrm{MW}$ from sugar cane bagasse, during sugar harvest, which lasts five months (Azucar, 2013).

\section{b. Nicaragua}

The energy matrix of Nicaragua consists predominantly of fossil fuels. However, the share of renewable energy has grown significantly in recent years. According to the Nicaraguan Energy Institute (2012), in 2011, 65\% of its energy derived from petroleum and diesel, $30 \%$ from renewable resources ${ }^{6}$ and $5 \%$ from large hydropower plants (HCG). The energy pattern of Nicaragua, which historically responds to a structural problem, made it a country with high dependence on imported oil (over $70 \%$ of thermoelectric generation with fuel oil and diesel in 2007). This situation has limited Nicaragua's economic development because of the growing trend in oil's international prices. (OLADE, 2011).

Nicaragua has more than 5,000 MW of potential capacity to generate renewable energy, of which 2,500 MW correspond to hydroelectric power, 1,500 MW to geothermal energy, $800 \mathrm{MW}$ to wind power and 200 MW to Biomass.

The Indicative Plan of Ministry of Energy and Mines (MEM) states that for 2017 only $6 \%$ of generated electric energy will come from thermoelectric plants, contrasted with $65,3 \%$ in 2010 (OLADE, 2011). It will increase generation from 3,321 GWh for 2010 to 4,823 GWh in 2017, with great participation of hydropower and geothermic energy, with $41 \%$ and $35 \%$ of total generation. (MEM, 2011b)

Even though renewable energy is a step forward, there is a long way ahead before it can be seen also as "sustainable" energy. The country needs investments to change fuel wood consumption patterns and associated deforestation, as well as a stronger regulatory capacity to ensure that big investments for the construction and operation of renewable electric energy also meet the required environmental standards.

In a recent publication from the United Nations Environment Program (UNEP, 2008), which compares emissions in Latin America, Nicaragua is the Mesoamerican country reporting fewer emissions per capita, ranking among the four countries of Latin America with lower emissions. Nevertheless, the change in the electric matrix will mean a significant emission reduction.

\subsection{South America}

\section{a. Brazil}

Brazil has one of the most privileged energy matrices of the world, with almost half of the energy $(44,1 \%)$ arising from renewable sources, while the world average is $13,3 \%$, and in developed countries, only $8 \%$ (Ministry of Mines and Energy - MME, 2012). The main renewable sources in the energy matrix are: sugar cane biomass $(15,7 \%)$, hydropower $(14,7 \%)$, firewood and charcoal $(9,6 \%)$, lixivium and others $(4,1 \%)$.

Regarding electrical power generation, the Brazilian scenario is even more sustainable, with $88,5 \%$ of renewable sources. According to the National Energy Report (NER, 2012), produced by the Energy Research Company Brazil, the renewable electricity production expanded by 2,5 percentage points in 2011, due to favorable hydrological conditions and increased wind generation. Brazilian power model remains heavily dependent on hydropower, which represents large dependence on current and future sector in relation to water use available in the country.

The electricity generation in Brazil increased $3,1 \%$ in 2011 over 2010 , reaching $531.8 \mathrm{TWh}$. The main generators are the public utilities, with $85,5 \%$ of total generation, which uses hydropower as the main source. The electricity generation from fossil fuels has decreased, with $18,9 \%$ of the national total in 2011 against $21,4 \%$ in 2010 (EPE, 2012).

\footnotetext{
${ }^{6}$ Composed by $5 \%$ small hydropower (SHP), $6 \%$ wind, $8 \%$ geothermic and $11 \%$ biomass and wastes.
} 
The sectors that consume the most overall energy are: industry $(35,9 \%)$, followed by transportation $(30,1 \%)$, residential $(9,5 \%)$, energy sector $(8,9 \%)$, commercial and public services $(4,4 \%)$ and agriculture (4\%). Industrial production, freight transport and mobility of people and families represent $66 \%$ of energy consumption in the country (NER, 2012).

To produce and consume energy, every Brazilian emits on average 2 tons of $\mathrm{CO}_{2}$ per habitant $\left(\mathrm{tCO}_{2} / \mathrm{hab}\right)$, which is four times less than Europe $\left(7.1 \mathrm{t} \mathrm{CO}_{2} / \mathrm{hab}\right)$, nine times less than the United States $\left(16.9 \mathrm{t} \mathrm{CO}_{2} / \mathrm{hab}\right)$ and less than half of China (5.1 $\left.\mathrm{t} \mathrm{CO}_{2} / \mathrm{hab}\right)$.

The Brazilian government has developed policies and programs to promote research, development and innovation projects for power generation from renewable sources, such as the Incentive Program for Alternative Sources of Energy (PROINFA), the National Program for Production and Use of Biodiesel and the National Agroenergy Plan, which will be presented on section 4.

\section{b. Ecuador}

Ecuador's energy matrix has changed during the years, but in general, the two dominant sources of energy in the country, for 2008 , were petroleum $(81 \%)$ and hydropower (9\%). The modernization of the country has manifested itself in the structure of the energy matrix. While in $197044 \%$ of the matrix was based on the traditional use of biomass (charcoal and firewood, mainly), in 2008 it was only $6 \%$. There were a $50 \%$ increase in fossil fuel based energy and $9 \%$ in hydroelectricity in the same period (OLADE, 2011). A key political factor that has influenced the energy matrix is the subsidies to petroleum derivatives, which in turn contributes to an unsustainable energy use. Due to the high dependence on few energy sources and high petroleum use generated in the energy matrix, the government has proposed a matrix reversion as a strategy of their Good Living National Plan ${ }^{7}$ (Centro Ecuatoriano de Derecho Ambiental - CEDA, 2011).

This new matrix is based on a rise in the national production of renewable energy, and the promotion of projects using alternative energy such as those financed by the Fund for the Electrification of the Rural and Marginal Urban (FERUM $)^{8}$ (FEDETA $^{9}$, 2013). The strategy of this proposal includes the development of big hydroelectric plants especially in the Amazonian watershed. In this respect, $86 \%$ of the expansion projected for 2020 is based on hydroelectric sources, and $6 \%$ on other renewable sources (CEDA, 2011). Regarding $\mathrm{CO}_{2}$ emission, in 2010 Ecuador emissions per capita were about 2,2 metric tons, the same level of Brazil, and below Chile $(4,2)$ and Mexico (3,8) (World Bank, 2013).

\section{c. Chile}

The energy matrix of Chile is composed by $90 \%$ petroleum, $4 \%$ natural gas, 3.3\% hydropower, $1.4 \%$ sugar cane, 1,3\% firewood (Ministry of Energy - ME, 2012).

Chile has a strong external dependence associated with the import of energy used, which in 2011 was around $78 \%$ of the country's total energy matrix (ME, 2013). Imported energy is consumed in the form of coal, petroleum and gas. This situation exposes the country to variations of international fuel prices raising the final costs of the energy, which are transferred to consumers. The Chilean energy matrix is primarily based on thermoelectric and hydroelectric energy.

The Chilean electric matrix comprises two electrical systems of great extent: the Central Interconnected System (SIC), which corresponds to $73,6 \%$ of total installed capacity; the Large North Interconnected System (SING), which represents 25,6\%, and four minor electrical systems: Aysen Electrical System, Magallanes Electrical System, the Lakes Electrical System, and the Easter Island Electrical System. These electric grids are configured by installations of generation stations, electric substations, transmission lines and distribution lines that interconnect all of the projects described above. Currently the electric energy generated by renewable sources reaches $5,06 \%$ of the installed capacity of the national energy matrix, considering for these calculations the

\footnotetext{
${ }^{7}$ The National Action Plan 2009-2013 has 12 targets to meet the needs of the communities. One of the targets is "guaranteeing the sustainability of the natural heritage through the rational and responsible use of renewable and non-renewable natural resources" (Republic of Ecuador, 2010) ${ }^{8}$ FERUM, Ecuadorean government program that aims to provide energy to rural and marginal urban areas of the country.

${ }^{9}$ FEDETA, foundation that works since 1984, which helps to improve the quality of life of the rural area, through the use and application of technologies.
} 
biomass energy, wind energy, solar energy and hydroelectric energy less than 20MW.

The SIC electric matrix is composed by $45 \%$ hydropower, $22 \%$ diesel, $15 \%$ coal, $13 \%$ liquefied natural gas, $3 \%$ biogas and $2 \%$ biogas, while the SING electric matrix is composed by $52 \%$ coal, $28 \%$ diesel, $19 \%$ LNG and $1 \%$ biomass, with no hydropower (Ministerio de Energía, 2013).

The $\mathrm{CO}_{2}$ emissions in Chile have increased during the years. In 1990, the $\mathrm{CO}_{2}$ emissions per capita were 2,6 metric tones, and in 2010, 4,2 - an increase of $60 \%$ (World Bank, 2013).

\section{Methodology}

The following study uses a qualitative analysis to identify aspects that should shape the development of renewable energy, with the objective of establishing successes and failures in public policies linked to this subject within the context of climate change and renewable energies. Figure 1 presents the selected Latin American Countries studied in this article.

The methodology consists of a state-of-the-art literature review in academic articles, institutional reports, books, government reports and official national docu-

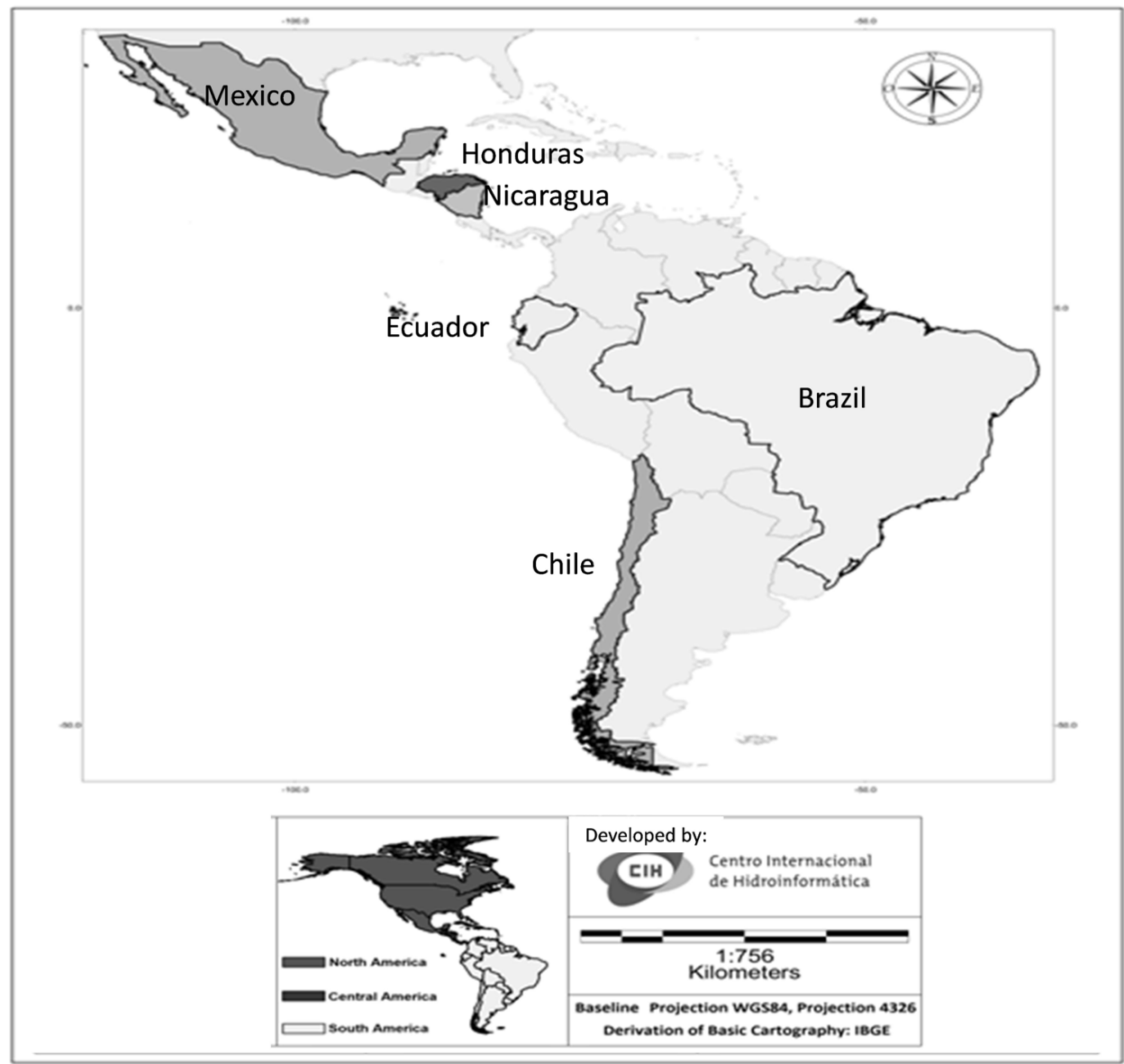

FIGURE 1 - Countries involved in the Study.

SOURCE: International Hydroinformatics Center- Brazil (2013) 
ments about Latin American trends in renewable energy sources, and in the scenario of renewable energy in each country, including the energy matrix ${ }^{10}$ and $\mathrm{CO}_{2}$ emissions. Considering that water and energy are intricately linked, we will analyze and compare the energy consumption and the annual freshwater withdrawals and electric power consumption. Scott and Pasqualetti (2010) affirm that managing water and energy separately is "shortsighted and inefficient". Treating them together, on the other hand, will broaden the identification of emerging sustainability challenges and lead the way for the increasingly difficult challenges that decision-makers face; many of who entertain "positive illusions" about the ease of future policy choices. After this analysis, we will consider comparative perspectives on public policy and we will synthesize the findings derived from individual countries, and present a preliminary prognosis for Latin America.

Energy consumption is a reflection of energy production in the different possible schema. Figure 1 presents a comparative schematic of the energy consumption behavior, as a result of its raw material and generation process. In this way it represents the consumption associated to fossil fuels, renewable fuels and waste ${ }^{11}$. Alternative and nuclear energy ${ }^{12}$, as well as carbon dioxide emissions, from this indicator are valid for Latin America and the Caribbean, as the world average for 2010 is shown. The average energy consumption scenario in Latin America and Caribbean for 2010 was: 73\% of fossil fuel energy, $16.5 \%$ of combustible renewable and waste and $10,5 \%$ of alternative and nuclear energy, all of them from total energy consumption (World Bank Data Base, 2013).

In Figure 2, GDP $P^{13}$ (current US\$), Annual freshwater withdrawals ${ }^{14}$ and Electric power consumption ${ }^{15}$ are observed, all of them per capita. The aforementioned indicators were extracted from the World Bank Indicator Catalog and were used due to availability of information for all the countries involved.

Subsequently we will consider comparative perspectives with an explicit focus on policy and regulatory questions, presenting the implications of policies against these scenarios from the perspective of the energy sector in Latin America and Caribbean. Lastly, we will conclude by synthesizing the findings derived from individual countries and present a preliminary prognosis for Latin America.

\section{Results}

\subsection{Comparison of energy scenarios of the involved countries}

All countries have different realities; therefore general parameters need to be established in order to

\footnotetext{
${ }^{10}$ The energy matrix of a country is all energy available to be processed, distributed and consumed in production processes, which expresses the amount of energy resources offered by a country or a region. An energy matrix is a key element in the strategic planning of a country's environmental, human development, and economic objectives. Viewed across a region as diverse as Latin America, energy matrices reveal opportunities and constraints that need to be challenged and each country has a duty to develop public policies to overcome this scenario (OLADE, 2011).

${ }^{11}$ Combustible Renewable fuels and waste comprises solid biomass, liquid biomass, and industrial and municipal waste (IEA, 2013).

${ }^{12}$ Alternative and nuclear energy refers to clean energy that is non-carbon sources of energy that does not produce carbon dioxide when generated. It includes hydropower and nuclear, geothermal, and solar power, among others (IEA, 2013).

${ }^{13}$ GDP per capita is gross domestic product divided by midyear population. GDP is the sum of gross value added by all resident producers in the economy plus any product taxes and minus any subsidies not included in the value of the products. It is calculated without making deductions for depreciation of fabricated assets or for depletion and degradation of natural resources. Data are in current U.S. dollars (IEA, 2013). World Bank national accounts data, and OECD National Accounts data files.

${ }^{14}$ Annual freshwater withdrawals refer to total water withdrawals, not counting evaporation losses from storage basins. Withdrawals also include water from desalination plants in countries where they are a significant source. Withdrawals can exceed 100 percent of total renewable resources where extraction from non-renewable aquifers or desalination plants is considerable or where there is significant water reuse. Withdrawals for agriculture and industry are total withdrawals for irrigation and livestock production and for direct industrial use (including withdrawals for cooling thermoelectric plants). Withdrawals for domestic uses include drinking water, municipal use or supply, and use for public services, commercial establishments, and homes. Data are for the most recent year available for 1987-2002. Food and Agriculture Organization, AQUASTAT data.

${ }^{15}$ Electric power consumption measures the production of power plants and combined heat and power plants less transmission, distribution, and transformation losses and own use by heat and power plants. International Energy Agency (IEA, 2013).
} 


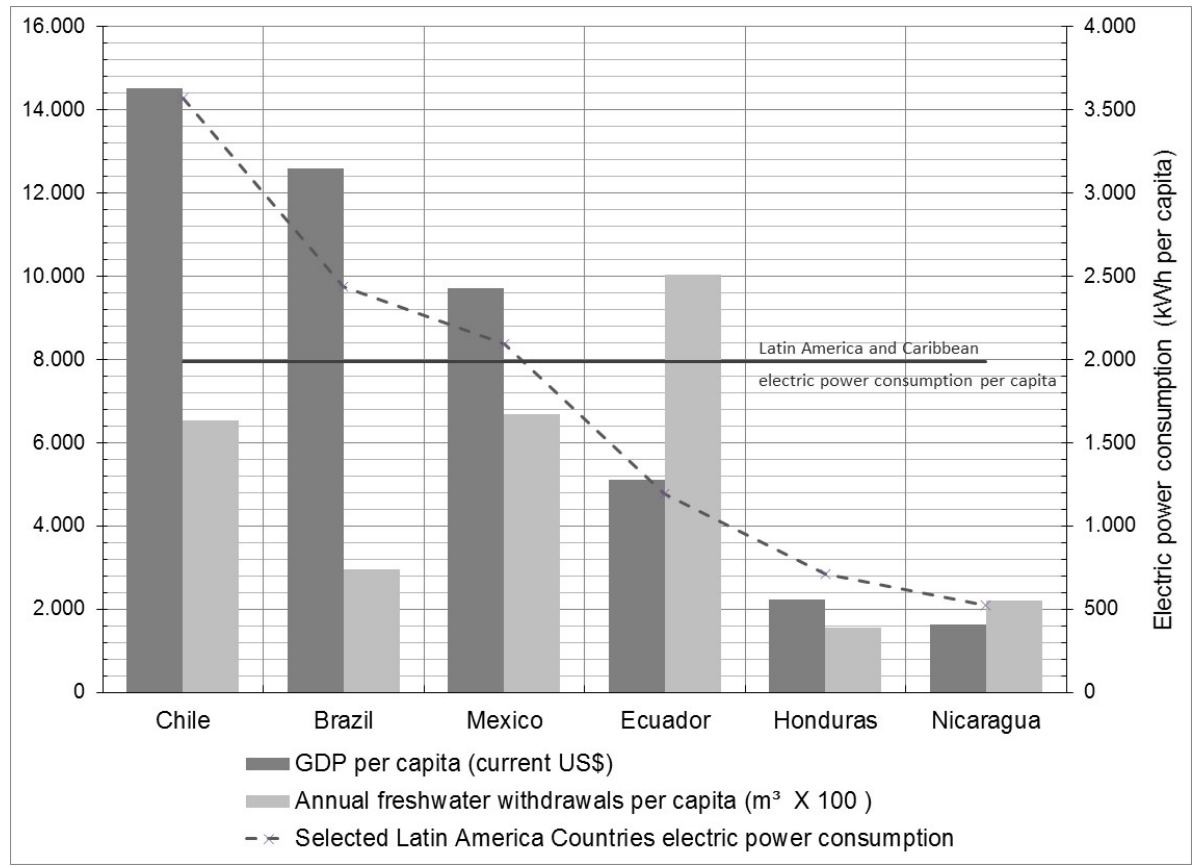

FIGURE 2 - GDP, Annual freshwater withdrawals and Electric power consumption for 2011.

SOURCE: World Bank Catalog (2010)

compare them ${ }^{16}$. Table 1 compiles general basic characteristics of the countries in this study.

Brazil has the largest territory extension of the studied countries ${ }^{17}$, followed by Mexico, Chile Ecuador, Nicaragua and Honduras. It is important to review the urban population percentage within each country because energy and water consumption is a reflection of the development and urbanization of a country. If urban centers increase, there is a higher demand for the development of infrastructure and provision of services.

Although urban population data observed in Table 1 correspond to 2012, according to the information reported by the database of the World Bank, these values have not had any significant changes in the last years. For the countries considered in this study, Chile has the highest percentage of urbanized population (89\%), followed by Brazil ( $85 \%$ ). In this sense, the rate of expected population for 2030 (population growth percentage with respect to 2012) in the case of Honduras and Ecuador comes to attention.

The dynamic of the water cycle influences the disposition of water in quantity and quality, as well as of other resources. Evapotranspiration, precipitation and filtration depends greatly on the type of land cover. The cases of Honduras and Ecuador should be highlighted, because they report a loss of forest cover of more than two percent in the last four years. Chile, on the other hand, not only has conserved their forest area, but has also sought to increase it. In Latin America and the Caribbean there is still a $48 \%$ forest cover area, a high value in comparison to other areas of the world such as Europe and Central Asia that only have 10\% forest cover, or the world average of 30,9\% of forest cover (World Bank Data Base, 2013).

\footnotetext{
${ }^{16}$ In order to obtain annual per capita values, the second mentioned indicator, the available values were divided between the total population for the same year 2011 .

${ }^{17}$ Brazil is the fifth largest country in the world, behind Russia, Canada, China and the United States.
} 
TABLE 1 - General information in selected Latin American Countries.

\begin{tabular}{|c|c|c|c|c|c|c|c|c|}
\hline Brazil & $8,515.767$ & $198,656.019$ & 85,00 & 19,81 & 98,70 & 89,40 & 61,90 & 61,20 \\
\hline Chile & $756,950.00$ & $17,464.814$ & 89,00 & 12,15 & 99,40 & 96,80 & 21,70 & 21,90 \\
\hline Ecuador & 283,560 & $15,492.264$ & 68,00 & 35,55 & 92,20 & 79,40 & 41,30 & 38,90 \\
\hline Honduras & 112,090 & $7,935.846$ & 53,00 & 42,39 & 79,90 & 86,80 & 48,50 & 45,30 \\
\hline
\end{tabular}

Regarding the energy consumption, in Latin America oil remains the most important fuel in primary energy supply, with $45 \%$, followed by coal and natural gas. Fossil fuels represent about $70 \%$ of the regional energy supply in 2005 (against 63\% in 1971), in line with the global trend. The domain of fossil sources in regional energy has changed little since 1971 (CEPAL, 2008). Although hydropower has been the main energy source of electricity for Central America in the renewable energy scenario, the region is now also emerging as an important producer of ethanol with the main market being the United States of America (Apergis, 2011).

Figure 3 shows that there is an ample dependence on the generation and consumption of fossil fuels in the countries involved in this study.

It is possible to verify that, in 2010, Mexico had the highest percentage of fossil fuel energy consumption $(89 \%)$, followed by Ecuador (88\%), Chile (78\%), Brazil (53\%), Honduras (51\%) and Nicaragua (45\%).

The consumption of combustible renewables and waste consumption is higher in Honduras (43\%), followed by Nicaragua (41\%), Brazil (31\%), Chile (16\%), Ecuador (5\%) and Mexico (4\%). The comparison in alternative and nuclear energy consumption shows that its level is higher in Brazil (14,7\%), followed by Nicaragua $(10,1 \%)$, Chile and Ecuador (6,1\%), Mexico (6\%) and Honduras (5,6\%) (World Bank Data Base, 2013).

Regarding the $\mathrm{CO}_{2}$ emissions, Latin America and Caribbean have low representation in global emissions of $\mathrm{CO}_{2}$ associated to the energetic sector (3,5\% in 2005), only higher than Africa (3,1\%), and there are no large projected variations in the participation of the region in 2005-2030 scenarios. It is estimated that this would be $3,9 \%$ in 2030 in the worst case of absence of policies (business as usual). According to table 2, Latin America and the Caribbean are also below the world average in $\mathrm{CO}_{2}$ emissions per capita $\left(\mathrm{tCO}_{2} / \mathrm{hab}\right), 1,5$ times lower than Middle East and North America, and two times lower than Europe and Central Asia. The $\mathrm{CO}_{2}$ emissions per capita and per unit of output in Latin America are still among the lowest in the world (CEPAL, 2008).

TABLE 2 - World $\mathrm{CO}_{2}$ emissions per capita in 2010.

\begin{tabular}{ccc}
\hline Developing regions & $\begin{array}{c}\mathrm{CO}_{2} \text { emis- } \\
\text { sions in 2010 } \\
\text { (metric tons } \\
\text { per capita) }\end{array}$ & $\begin{array}{c}\text { Urban } \\
\text { Population } \\
\text { in 2012 } \\
(\% \text { of } \\
\text { total) }\end{array}$ \\
\hline Sub-Saharan Africa & 0,8 & 37 \\
South Asia & 1,4 & 31 \\
Latin America \& Caribbean & 2,7 & 79 \\
Middle East \& North Africa & 3,9 & 60 \\
East Asia \& Pacific & 4,9 & 50 \\
Europe \& Central Asia & 5,3 & 60 \\
\hline
\end{tabular}

SOURCE: World Bank Catalog (2010) 


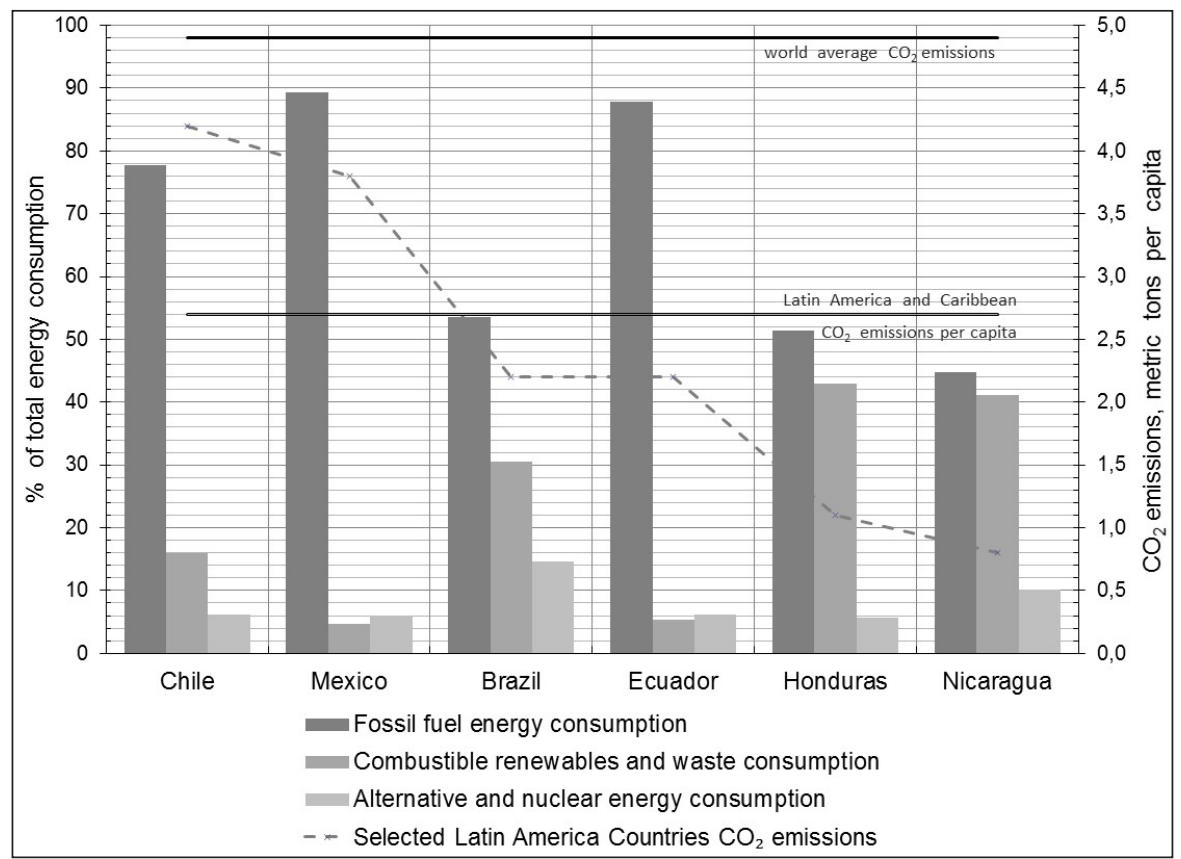

FIGURE 3 - Energy Consumption Scenarios in selected Latin American Countries for 2010.

SOURCE: World Bank Catalog (2010)

In the case of Chile and Mexico, there is much to do if we observe the carbon dioxide emissions, which are greater than the average of Latin America and the Caribbean.

Figure 2 will present the scenario of GDP, Annual freshwater withdrawals and Electric power consumption among the involved countries.

Regarding GDP per capita (current US\$) of each country in 2011, Nicaragua has the smallest economy in the region $(1,632)$, followed by Honduras $(2,241)$, Ecuador (5,096), México (9,703), Brazil (12,756) and Chile $(14,513)$. Because of the importance of the water-energy nexus and based on data available in selected countries, a comparison of Annual freshwater withdrawals $\left(\mathrm{m}^{3} \mathrm{x} 100\right)$ and Electric power consumption (kWh per capita) for the same year is made. Ecuador has the highest Annual freshwater withdrawals $(10,035.10)$, followed by Mexico $(6,685.59)$, Chile (6,528.60), Brazil $(2,950.21)$, Nicaragua $(2,201.47)$ and Honduras $(1,543.08)$. It is possible to verify that Chile $(3,568)$ has the highest Electric power consumption per capita, followed by Brazil $(2,438)$, Mexico (2,092), Ecuador (1,192), Honduras (708) and Nicaragua (522) (World Bank Data Base, 2013).

\subsection{Comparison of Public Policy implications of the energy scenario}

According to Scott and Pasqualetti (2010), "policy initiatives that view energy and water in joint management terms, and that more fully unlock the potential of conservation, efficiency, and renewable energy sources are required. This is not simply a question of planning for optimal resource use." The authors affirm that "collaborative policy-making that involves public decision-makers, private initiative, and a range of stakeholders will be needed to counter special-interest groups' influence over infrastructure development and energy and water policy." 
In this sense, policies that can be implemented to alleviate energy insecurity are: 1) to manage risks to avoid disruptions in the supply, 2) to overcome the lack of generation capacity, 3) to facilitate access to renewable sources and 4) to change the energy matrix and its dependence on imported energy. (CEDA, 2013)

Some public policies on water and the energy nexus developed by the countries involved in this study will be presented below.

\subsubsection{North America}

\section{a. Mexico}

Currently Mexico has the highest $\mathrm{CO}_{2}$ emissions of the rest of Latin America and the Caribbean, despite having a lower energy consumption compared to Brazil and Chile. However, Mexico has developed important projects and public policies that seek to consolidate strategies to strengthen the energy industry, which is in a stage of great changes and transformations.

Mexico's energy policy seeks to insure the supply of energy inputs that are required by the economy, as well as strengthen public companies of the sector to improve the opportunity and quality in the supply of energetic inputs, and intensely promote the energetic efficiency and the use of renewable energy. The objective of this policy is to diversify energy sources and diminish the environmental impact that is derived from the use of fossil fuels. This includes the Law for the Promotion and Development of Bioenergetics, as well as the National Program for Sustainable Use of Energy that seeks to reduce energy consumption in highly populated areas by defining lines of action starting from the analysis of the objectives and strategies to increase energy efficiency in the medium and long term.

The National Energy Strategy 2013-2027 (MEXICO, 2013) establishes objectives, goals and action lines that will allow the energy sector to grow towards a sustainable horizon. It includes three major axis: economic and productive efficiency ${ }^{18}$, energy security ${ }^{19}$ and environmental sustainability ${ }^{20}$. The Law for the Renewable Energy Use and The Financing of the Energetic Transition is a key element for the matrix reversion as it creates a fund as a tool for the fulfillment of the National Energy Strategy and the subsequent energy matrix transition. It is expected by 2030 a reduction of up to 4,017 terawatt hour (TWh), which represents approximately three years of final energy consumption at the current rate.

In accordance with Objective 5.3 of the National Energy Strategy, which states the diversification of energy sources to increase the participation of clean energy, by 2010 there had been an installed wind power capacity of $500 \mathrm{MW}$ among public and private projects, which is expected to expand to 2,200 MW, an estimated $4 \%$ of the Mexican energy matrix. Permits for the production of bioenergetics have been granted, and two plants for the production of biodiesel have opened among others (MEXICO, 2011).

Following objective 5.4 of the National Energy Strategy, which seeks to reduce the environmental impact of the energy sector, one of the most successful programs has been the "Substitution of Home Appliances for Energy Saving" that promotes the substitution of refrigerators and air conditioners that are over 10 years old for new energy saving appliances (MEXICO, 2011).

\footnotetext{
${ }^{18}$ The Law for the Promotion and Development of Bioenergy was approved in February 2008. It is intended to contribute to energy diversification and sustainable development in addition to achieving the reduction of emissions to the atmosphere and greenhouse gases, setting sectoral and annual programs for their production, storage, transportation, distribution, marketing and efficient usage. The Bioenergy Introduction Program aims at the development in the production and consumption of bioenergy as an alternative for its incorporation in the mix fuels for transportation, avoiding national food competition. <http://www.bioenergeticos.gob.mx/index.php/programas/marco-legal.html >.

${ }^{19}$ The National Program for Sustainable Use of Energy identifies opportunities to achieve optimal energy use in every process and activity for exploration, production, processing, distribution and consumption, including energy efficiency, generating savings for the country in the medium and long term. <http://www.conuee.gob.mx/wb/CONAE/pronase_20142018>.

${ }^{20}$ The Law for the Renewable Energy Use and The Financing of the Energetic Transition was published in 2008, with the goal to regulate the renewable energy sources use and clean technologies in order to generate electricity for different purposes than the public electricity provision. It sets the national strategy and the instruments for financing energy transition.
} 


\subsubsection{Central America}

\section{a. Honduras}

Since 1957, during the creation of the National Energy Company (Empresa Nacional de Energía Eléctrica-ENEE), the Honduran legislation began its way towards renewable energy. The reform of the electrical industry promotes the use of renewable energy through different incentives included in the Framework Law for the Electric Subsector (1998), which states that energy from clean sources can be bought by the government with a $10 \%$ margin above the marginal cost in short term as well as the exoneration of income tax during the first five years of commercial operation. Additionally, the state guarantees the purchase of all energy from renewable energy sources for electric plants with a capacity of under 50MW (Decree 9-2001). Lastly Decree 103-2003 facilitates all legislative procedures, such as approval in one debate instead of the three required from renewable energy producers.

Honduras has a national plan which establishes in Objective \#3 subsection 3.3 "Increase the participation in the energy matrix of renewable energy to $80 \%$ by the year 2022" (Comisión Técnica Plan de Nación, 2010). Additionally it is the only Central American country to have a law that regulates biofuels and provides incentives for clean energy production (Flores, 2012). Currently the country is betting on wind, biomass and hydro power, with two hydro electric power plants, "El Cajon", with an established capacity of $300 \mathrm{MW}$, and the Jicatuyo, with an established capacity of $210 \mathrm{MWh}$, as well as the construction of two additional hydro power centrals: Patuca III, which will be able to produce $100 \mathrm{MW}$, and los Llanitos, with 80 MW (ENEE, 2012). A biomass plant estimated to produce $35 \mathrm{MW}$ is under construction with its first stage inaugurated in April 2012, (Departamento 19, 2012) and its final stage programmed for 2014 (Radioamerica, 2012).

Honduras energy consumption, much like most of the world's countries, is closely correlated to its GDP (Figure 3). However, it can be inferred that its economic activities do not depend solely on water extraction since this last factor is slightly lower than its GDP and almost $50 \%$ lower than energy consumption for the country
(World Bank Catalog, 2010). Figure 3 clearly shows the current pattern of energy production that Honduras has been following since the 1980 s, with its majority coming from petroleum products.

However, in accordance to its current energy policies, Honduras is promoting the implementation of renewable energy sources through a strategy that plans to reverse its energy matrix by the year 2022. As a result of these policies, 52 projects for the generation of renewable energy were approved by the Honduran Congress in 2010. These projects include 49 micro hydroelectric plants and three biomass plants that will signify a $60 \%$ of the entire energy matrix (Heraldo, 2010). Such project is Patuca III, which is now in phase II of its implementation, which comprises the installation of the distribution lines (Tribuna, 2013) and will generate $104 \mathrm{MW}$. But not only is the use of renewable energy sources being sought in the public sector but also the private sector. Caracol Knits, which is a textile manufacturer, has an ongoing project to generate electricity for self-consumption through the use of biomass, in addition it is strengthening its water management through treatment plans for their water waste (CII, 2013).

As well as reducing emissions and dependency on petroleum, the country is seeking to reduce costs for energy. The Chamelecon 280 reservoir will save the government of Honduras 31 million Lempiras (US\$ 1,5 million) through the generation of $12,8 \mathrm{MW}$ of energy, since in Honduras, due to the type of subscribed contracts, hydroelectric energy costs a third of the energy generated through the use of petroleum products.

\section{b. Nicaragua}

"With the implementation of the Strategic Plan for the Energy Sector of Nicaragua, conditions are being created for the development of renewable energy through public and private projects that use the available potential of renewable energies" (OLADE, 2011). One of the goals presented in the Electric Generation Expansion Plan is that it is expected that in 2017 about $94 \%$ of the electric energy matrix will depend on renewable sources, with hydropower and geothermal energy representing 77\% of the total generation (Mines and Energy Ministry MEM, 2011b) and the balance coming from wind and solar power. 
The Nicaraguan Energy Policy has three main axes: (1) energy matrix diversification focusing on renewable resources; (2) energy efficiency; and (3) rural electrification. The Nicaraguan government expects to revert their current electric energy matrix from $65 \%$ (based on fossil fuel) to $94 \%$ renewable energy by 2017 (Trucchi, 2010). As a result of the country's energy policy a $63 \mathrm{MW}$ of wind energy has been added to the matrix.

Even though Nicaragua has the lowest GDP of all the countries in the present study (US\$ 1,600), it has the highest alternative energy consumption with the exception of Brazil. Additionally, it is the only country that consumes more biomass than fossil fuels. This is the result of the implementation of several campaigns and programs. One example is the Educational Campaign, which targets schools and seeks to inform 12 possible steps to save energy and the need for sustainable energy consumption that has reached 13,000 teachers, 400,000 students in 1,050 schools so far. Furthermore it must fulfill the approval of a Mandatory Technical Norm addressing the energy efficiency of residential appliances.

Since 2007, several measures have been implemented as part of a national strategy to face energy deficit in the country. "For example, initial priorities were the creation of the Ministry of Energy and Mines, the installation of additional $343 \mathrm{MW}$ in the National Interconnected System (mainly based on bunker and diesel, for the urgency of the situation), and the development of the first renewable energy projects" (OLADE, 2011).

Nicaragua's Generation Expansion Indicative Plan for 2011-2016 has included several renewable energy projects (e.g., wind, hydroelectric and geothermal) that will generate $90 \%$ of the electricity generated in the country. This energy matrix reversion will be a great contribution to reduce $\mathrm{CO}_{2}$ emissions.

The legal and institutional framework of the electricity sector is given by Law $272^{21}$. This law has been reformed on several occasions as shown in the legal framework. For example, in 1998, with the approval of Laws 272 and 271, the reforms as of 1990 were consolidated: Law 272 established the basic principles for the operation of a competitive wholesale market with the participation of private companies, while Law 271, the INE Reform, conducted the creation of the National Energy Commission (CNE) that assumed the responsibilities of the creation of policies and plans.

Furthermore, law 272 (Law of Electrical Industry - LIE) creates the National Energy Commission attached to the Executive as the governing institutional body in charge of the sector policies, strategies and plans. The Law of the Electrical Industry, issued in 1998, formed the basis for the participation of the private sector in the Nicaraguan electrical industry, both in generation and distribution. The wholesale market is created as a result of this reform, which is made up of a contract market and a second-hand market. This legal framework is an incentive to investors for renewable energy projects, an example of which is the German government, which has already invested several millions in projects in Nicaragua (MEM, 2012).

\subsubsection{South America}

\section{a. Brazil}

For the first time in its history, Brazil has a document that facilitates the estimation of the supply and demand of energy for a period of 25 years. Based on data from the National Energy Plan 2030 (NEP 2030), it is possible to devise strategies and develop policies that ensure the safety and quality of energy supply for the next decades. From 2005 to 2030 it is expected an increase of $3.7 \%$ per year in energy demand, with the presence of renewable sources being increasingly significant in the Brazilian energy matrix, corresponding to $45 \%$ of all energy consumed in the country (NEP 2030). The renewable sources scenario in 2030 will consist of: 39\% Small Hydroelectric Plant (SHP), 32\% biomass, $23 \%$ wind and $6 \%$ waste (EPE, 2007).

This scenario is possible due to the energetic efficiency of sugarcane for ethanol production and electricity generation, beyond the Amazon hydroelectric potential. It

\footnotetext{
${ }^{21}$ Law of the Electrical Industry, approved on March 18th, 1998 and published in La Gaceta No. 74 of April 23, 1998; and Law 271: Organic Law of the INE.
} 
is anticipated that the renewable sources scenario in 2030 will consist of: 39\% Small Hydroelectric Plant (SHP), $32 \%$ biomass, $23 \%$ wind and $6 \%$ waste, representing great advances in diversifying the energy matrix. (EPE, 2007).

The Brazilian government has developed policies and programs to promote research, development and innovation projects for power generation from renewable sources, such as the Incentive Program for Alternative Sources of Energy (PROINFA), the National Program for Production and Use of Biodiesel and the National Agroenergy Plan. Based on the current scenario and future prospects of global energy, the Brazilian government has developed policies and programs to promote research, development and innovation projects for power generation from renewable sources:

a) Incentive Program for Alternative Sources of Energy (Proinfa): regulated in 2004, the program aims at increasing the share of electricity produced by projects based on renewable sources in the National Interconnected System (SIN), such as wind, biomass and Small Hydroelectric Plant (MME, 2012).

b) National Program for Production and Use of Biodiesel: created in 2004, it aims at implementing sustainable production and use of biodiesel, focusing on social inclusion and regional development by generating employment and income.

c) National Agroenergy Plan: it aims at ensuring sustainability, competitiveness and greater equity (equal rights) between agents of agro-energy chains, in accordance with the expectations of society and public policy from the energy sector, social, environmental, and agricultural supply (Ministry of Agriculture, Livestock and Food Supply - MAPA, 2006)

Besides the national policies, Brazil has implemented important local projects in order to reduce the $\mathrm{CO}_{2}$ emissions and dependence of fuel sources. One of these projects is the Watershed of the river Ajuricaba Agroenergy Condominium for Family Agriculture, located in Paraná State (South Brazil) and developed by Itaipu Binational $^{22}$. The condominium has the participation of
33 properties, each one from 10 to 20 hectares, producing soybeans, corn, wheat, cattle and pigs, generating approximately 16 thousand tons of waste / year. The wastes generated by the production are converted in biogas, with three possibilities of conversion: electric energy, thermal energy and vehicle power. The generation of electric energy is used for self-consumption, the thermal energy is used by applying the biogas in the fed of a furnace, as an indirect source of heat in the grain dryer, which is used by producers belonging to the condominium, reducing the cost of grain drying to $90 \%$. In addition, some of the properties use the biogas in ovens for cooking foods in place of LPG (Liquefied Petroleum Gas) and also for heating water for cleaning dairy utensils, with the goal of improving the quality of milk and, consequently, the income generated by its sale. The vehicular application is possible from the conversion of biogas into biomethane, with high calorific value, a product of the treatment of biogas in the Biogas Treatment Unit (BTU). Besides the importance of the project in generating economic benefits for the farmers, it is an example of use of biogas in substitution of fossil fuels.

\section{b. Ecuador}

Since 2008, the constitution of Ecuador establishes that energy resources is a primary and strategic sector of the country, as it is also mentioned in the Plan for Good Living (Sumak Kawsay), where policies, strategies, goals and objectives for the diversification of the energy matrix are established. The practical path that these strategies draw are shown in the projects finalized in 2012, such as Ocaña, Buenos Aires, Jivino, Jaramijó and Santa Elena, with a total investment of 338,6 million dollars.

For the moment, the energy sector has a prevailing relevance, favoring the development of energy alternatives and at the same time as a source of income in the Ecuadorian economy through government investment. Additionally, the government is promoting strategies to use energy saving light bulbs, and so in the short term to be able to lessen the excessive energy consumption. Since the change in the energy matrix requires short-

\footnotetext{
${ }^{22}$ Itaipu Binational has unique characteristics regarding the legal status of the company, because it is not a state but a binational company, governed by a treaty signed by the governments of Brazil and Paraguay.
} 
-term measures, this will complement and integrate the medium and long-term plan, get the ultimate goal of not relying exclusively on oil, and promote diversity to the energy matrix of Ecuador.

The energy policy of Ecuador focuses on the production of hydroelectric energy through diverse important projects that seek self-sustenance, possibly resulting in Ecuador having the highest fresh water annual withdrawals than any other country in this study, but the second highest fossil fuel consumption only surpassed by Mexico. Additionally, there are complementary measures such as the 2009-2020 master electrification plan that intends to establish a national electrification net that offers and motivates the development of Ecuador's energy matrix. In conjunction with the Good Living Plan, the master electrification plan impulses the immediate execution of hydroelectric plants as well as other renewable energy sources. An example is the Villonaco wind farm that has generated 16,5 MW since 2013 and the Baltra wind farm, which began its construction in 2012 and is expected to produce 2,1 MW (Ministry of Electricity and Renewable Energy, 2011). This can be a result of the current reversion of the energy matrix in which most of its renewable energy is hydroelectric based.

\section{c. Chile}

Chile regulates the activity of the electrical sector through the General Electrical Services Law (LGSE currently DFL $\mathrm{N}^{\circ} 4$ ) passed in 1982, which has suffered posterior modifications. This law regulates the production, transport, distribution, concession and electric tariff, and posses a complementary regulation determining all together the technical and security norms for any electrical installation in the country. Within the modifications to the LGSE there are the Short Laws I and II that primarily regulate the level of quality and security of the electrical supply at reasonable prices, fixing prices and establishing solution mechanisms to conflicts of the sector through the implementation of an expert panel that acts as a tribunal (Electricidad, 2012).

In terms of public policies associated with renewable energy themes there is the Law of Energy Generation with Renewable Non-Conventional Energies (ERNC Ley 20.257), which establishes that in 2014 electrical companies must credit $5 \%$ of the yearly energy sold coming from renewable sources; this amount will increase $0,5 \%$ annually starting in 2015 until it reaches $10 \%$ in 2024 . Along with this law, the law for distributed energy in low tension (Ley 20.571) promotes the self-generation at residential level; even though this law has been approved, it will come into force until the associated regulation has passed.

Lastly Chile has a National Energy Strategy in which different guidelines refer to the country's energy matrix development vision to 2030. This strategy has 6 pillars; growth with energy efficiency, non-conventional renewable energy resources, higher importance of the hydro sector, new focus in electrical transmission, more competitive energy market, and a sustainable advance in the options of the regional electrical interconnection (Ministry of Energy, 2013). According to the strategy, by 2020 there should be a $12 \%$ energy demand reduction through different plans and actions such as energy efficient brands for the private sector, minimal technical requirements for appliances, and efficient residential and public illumination programs among others (Ministerio de Energía, 2012).

These six pillars constitute an integral plan that, together with the Law of Energy Generation with Renewable Non-Conventional Energies, is promoting the use of alternative energy resources that consequently are favoring environmental aspects such as the increase in forest cover that the Chilean territory is experiencing, as well as seeking a more sustainable energy scenario.

\section{Conclusions}

Water and energy are indispensable to the social and economic development of a country, and that progress implies the continued growth of economic activity. As a result, there are growing and populous cities, with a consequent rise in demand for energy and water. In this constant cycle, the world tirelessly searches for renewable energy from sustainable sources, which even should be the basis of a new energy model. Therefore, important hydroelectric and alternative energy projects are being developed in the medium and long run, which will allow a general energy supply and in some countries the possibilities of energy export. 
There are actions and strategies (Sustainable Light Program in Mexico, Chile's National Energy Strategy, Good Living Plan in Ecuador, PROINFA in Brazil, Nicaragua's Generation Expansion Indicative Plan and the Honduran Nation Plan) to diminish the use of petroleum and the promotion of renewable energy. Laws such as the Promotion of Energy Generation with Renewable Resources in Honduras, Energy Generation with Renewable Non-Conventional Energies in Chile, Renewable Energy Use and The Financing of the Energetic Transition in Mexico have allowed and promoted foreign and local investment in renewable energy projects that are the current trend in these Latin American countries.

Considering the current and future situation of the world's natural resources availability and in a context of climate change, it is imperative in every discipline the search for the optimization of natural resources management, which translates in energy consumption reduction. In that respect, the promotion of the use of new alternative energy sources in these Latin American countries will help reduce the environmental impacts. The incorporation of wind farms in Honduras (Cerro de Hula Wind Farm), the PROINFA project in Brazil (Lima, 2011) and Mexico's incentive in wind power production (MEXICO, 2011) are results of this promotion. Furthermore solar power projects such as the San Jose de Landa and Montecillos Solar Power project in Honduras, which will produce 40,000 MWh annually, and the Amanecer Solar CAP in the Atacama region of Chile, which will be the largest in Latin America generating $270 \mathrm{GWh}$ of energy annually, will also contribute to a reversion of the energy matrix towards renewable resources in these Latin American countries.

Some limitations in the countries mentioned in the study include access to technology and funding for the projects. Regardless of these constraints, the development of renewable energy in these countries is happening at a steady pace. Additionally, the public policy comparison in this study has resulted in a very positive outcome since all the countries involved have clearly defined policies and strategies as mentioned above.
Through comparative scenarios and analysis of public policy perspectives in the selected Latin American countries, a trend towards the development and use of renewable energy such as wind, biomass, photovoltaic and hydroelectric power can be identified. In most of these countries, policy makers are promoting the process of energy generation through the establishment of laws and policies favoring the renewable energy generation. The private sector is following the same path, and becoming aware of the importance of renewable energy sources versus petroleum based energy and, depending on its potential, most of them have begun the switch.

Subsequently, the transformation of the country's energy matrix requires not only the adoption of new instruments and specific policies (such as the recent price regulation favorable to electricity from renewable energy and incentives formulated to encourage the production of biofuels) but also a change in planning and structures that have shaped a matrix centered on fossil fuels (CEDA, 2012).

Finally the expansion of renewable energy can assist in reducing the dependence on foreign energy sources, the susceptibility of international oil prices and the long-term environmental impacts of carbon emissions. Furthermore according to Apergis (2011) renewable energy may not only rectify the current energy consumption mix but may also serve as a catalyst for the modernization of the country's energy sector in meeting sustainability objectives devised by policy makers.

\section{Acknowledgements}

International Hydroinformatics Center (CIH) Brazil, for the technical support; Pan-American Advanced Studies Institutes Program (PASI Grant No. 1242209) of the U.S. National Science Foundation for the financial support and the opportunity to attend the training in Chile; The National Autonomous University of Honduras, and Treatment and Reuse Group, Institute of Engineering, National Autonomous University of Mexico, for its support. 


\section{References}

Alvarenga, F. Pionero de la Energía Solar en Honduras. La Prensa, 2013. Available in: <http://www.laprensa.hn/ Publicaciones/Suplementos/Dinero-Negocios44/Pionero-de-la-energia-solar-en-Honduras\#.UgJuZG3EJ6A>. Accessed in: July, 2013.

Apergis, N.; Payne, J. The renewable energy consumption-growth nexus in Central America. Applied Energy, 88, 343347, 2011.

ARECA - Analisis del Mercado Hondureno de Energia Renovable. Banco Centroamericano de Integracion Economica 2010. Available in: <http://www.bcie.org/uploaded/content/ category/812316590.pdf $>$.

Arnette, A.; Zobel, C. The role of public policy in optimizing renewable energy development in the greater southern Appalachian mountains. Renewable and Sustainable Energy Reviews, 15(8), 3690-3701, 2011. 13 p.

AQUASEC - Center of Excellence for Water Security. PASI 2013: Training Institute on Adaptive Water-Energy Management in the Arid Americas. 2013. Available in: <http://aquasec. org/pasi2013 mainpage/>. Accessed in: August 2013.

AZUCAR. Se fortalece producción de energía por biomasa. 2013. Available in: <http://www.azucar.hn/web/?p=1384>. Accessed in: July 2013.

Banco Interamericano de Desarrollo. Programa Nacional de Electrificación Sostenible y Energía Renovable (PNESER)-II. 2011. Available in: $<\mathrm{http}: / / \mathrm{www}$.iadb.org/es/proyectos/project-information-page,1303.html?id=ni-11050\#.UmRPD_n6XT8>. Accessed in: July 2013.

Brasil. Brazilian Institute of Geography and Statistics (IBGE). Brazilian Territorial Area. 2010. Available in: <http://www. ibge.gov.br/home/geociencias/cartografia/default_territ_area. shtm>. Accessed in: July 2013.

Population reaches favorable demographic bonus to economic growth. 2012. Available in: $<\mathrm{http} / / /$ saladeimprensa. ibge.gov.br/noticias?view=noticia\&id $=1 \&$ busca $=1 \&$ idnotic ia $=1272>$. Accessed in: August 2013.

Energy Research Company (EPE). National Energy Report 2012. Available in: $<$ https://ben.epe.gov.br/downloads/ Resultados_Pre_BEN_2012.pdf $>$. Accessed in: August 2013.

. Ministério de Minas e Energia (MME). O PROINFA. 2012. Available in: <http://www.mme.gov.br/programas/ proinfa/>. Accessed in: August 2013.
. Ministry of Agriculture, Livestock and Food Supply (MAPA). National Agroenergy Plan. 2006. Available in: $<$ http://www.embrapa.br/publicacoes/institucionais/agroenergia_miolo.pdf $>$. Accessed in: August 2013.

National Institute of Meteorology (INMET). Conjuncture of Water Resources in Brazil. 2007. Available in: $<\mathrm{http}$ ://conjuntura.ana.gov.br/conjuntura/srh_precipitacao. $\mathrm{htm}>$. Accessed in: July 2013.

. Sustainable Brazil: Economic growth and potential consumption. 2008. Available in: $<\mathrm{http}: / /$ www.ey.com/Publication/vwLUAssets/Crescimento Econ\%C3\%B4mico e Potencial_de_Consumo_PDF_Publica $\% \mathrm{C} 3 \% \mathrm{~A} 7 \% \mathrm{C} 3 \% \mathrm{~A} 3 \mathrm{o} / \mathrm{SFILE} /$ Crescimento\%20Econ $\% \mathrm{C} 3 \% \mathrm{~B} 4 \mathrm{mico} \% 20 \mathrm{e} \% 20$ Potencial $\% 20$ de\%20Consumo.pdf $>$. Accessed in: July 2013.

Casallas, D. Complejo Aguan ofrecerá potencia de 220MW. 2012. BNAmericas. Available in: <http://www.bnamericas. com/news/energiaelectrica/complejo-aguan-ofrecera-potencia-de-220mw>.

Centro Ecuatoriano de Derecho Ambiental (CEDA). Hacia una matriz energética diversificada en Ecuador. 2012. Available in: <http://www.ceda.org.ec/descargas/publicaciones/ matriz_energetica_ecuador.pdf $>$. Accessed in: August 2013.

Chile. Instituto Nacional de Estadísticas (INE). Población total por sexo y años calendario estimada al 30 de junio. 1950 2050 En: Chile: Proyecciones y Estimaciones de Población. Total País 1950-2050 [PDF]. 2012. Available in: <http://www. ine.cl/canales/chile_estadistico/demografia_y_vitales/proyecciones/Informes/Microsoft\%20Word\%20-\%20InforP_T.pdf $>$. Accessed in: September 2013.

Universidad de Chile. Acerca de Chile: Presentación Territorial. 2013. Available in: <http://www.uchile.cl/portal/ presentacion/la-u-y-chile/acerca-de-chile/8035/presentacion-territorial>. Accessed in: September 2013.

Comisión Económica para América Latina y el Caribe (CEPAL). Fuentes Renovables de Energía en América Latina y el Caribe: Situación y propuestas de políticas. 2004. UNDP.

. Istmo Centroamericano: Estadísticas de Hidrocarbu$\overline{\operatorname{ros} .2009}$. Available in: <http://www.cepal.org/cgi-bin/getProd. asp? $\mathrm{xml}=/$ publicaciones/xml/4/37684/P37684.xml\&xsl=/ mexico/tpl/p9f.xsl\&base=/mexico/tpl/top-bottom.xsl $>$.

Corporación Interamericana de Inversiones. Proyectos. 2013. Available in: <http://www.iic.org/es/proyectos/honduras/ 
ho1042a-01/caracol-knits-sa-de-cv-ii>. Accessed in: August 2013.

Departamento 19. Honduras: en abril se inaugura planta de biomasa. 2012. Available in <http://www.departamento19. hn/index.php/economia/economia/4569-honduras-en-abril-se-inaugurara-planta-de-biomasa.html>. Accessed in: June 2013.

Devine, P. Local Aspects of UK Renewable Energy Development: Exploring Public Beliefs and Policy Implications. Local Environment, 10(1), 57-61, 2005.

Domínguez, S. Matriz energética de México. 2011. Available in: $<$ http://www.globalenergy.com.mx/index.php?option=com_co ntent\&view=article\&id=1021:matriz-energetica-de-mexico$-\&$ catid=59: de-interes\&Itemid $=151>$. Accessed in: August 2013.

Dorantes R. Las energías renovables y la seguridad energética nacional. 2008. Available in: $<$ http://academiadeingenieriademexico.mx/archivos/coloquios/5/Las\%20Energias $\% 20$ Renovables $\% 20 y \% 201 a \% 20$ Seguridad $\% 20$ Energetica $\% 20$ Nacional.pdf $>$. Accessed in: August 2013.

Ecuador. National Plan for Good Living: 2009-2013. 2010. Available in: <http://www.unosd.org/content/ documents/96National\%20Plan $\% 20$ for $\% 20$ Good $\% 20 \mathrm{Li}$ ving\%20Ecuador.pdf>. Accessed in: September 2013.

El Heraldo. 600 millones de dólares será inversión en Energia Renovable. 2010. Available in: <http://archivo.elheraldo.hn/ content/view/full/455214>. Accessed in: August 2013.

. Represa Chamelecon costara 34 millones de dólares. 2010. Available in: <http://archivo.elheraldo.hn/Ediciones/2010/09/14/Noticias/Represa-Chamelecon-costara-34-millones-de-dolares>. Accessed in: August 2013.

Environmental Protection Agency - US. Hydroelectricity. 2013. Available in: <http:/www.epa.gov/cleanenergy/energy-and-you/affect/hydro.html>. Accessed in: August 2013.

FAO. Reunión Regional sobre Generación de Energía Eléctrica a partir de Energía Renovables. 1996. Deposito de Documentos de la FAO. Available in: <http://www.fao.org/docrep/t2363s/ t2363s0x.htm>.

Fermosell, R. La Energia Solar Fotovoltaica toma impulso en Choluteca, Honduras. Suelo Solar, 2013. Available in: $<$ http:// www.suelosolar.es/newsolares/newsol.asp?id=8826\&idp=\&id ioma $=$ es\&idpais $=>$.

Flores, W. C. El Sector Energetico de Honduras: Diagnostico y Politica Energetica. Sistema de Información y Registro de los Investigadores de Honduras, 2012. p. 1-20.
Honduras. Comisión Técnica Del Plan De Nación. Republica de Honduras Vision de Pais 2010 - 2038 y Plan de Nación 2010 - 2022. Tegucigalpa, 2010.

Empresa Nacional de Energia Electrica - ENEE.

Proyecto Hidroelectrico Piedra Amarilla o Patuca III. 2012. Available in: <http://enee.hn/index.php/proyectos-renobables/ patuca-iii $>$. Accessed in: June 2013.

. Ley No. 104-93. (1993, del 30 de Junio). Ley General del Ambiente. Diario Oficial La Gaceta No. 27, 083.

. Ley No. 144-2007. (2007, del 31 de Diciembre) Ley para la Producción y Consumo de Biocombustibles. Diario Oficial La Gaceta No. 31, 496.

Ley No. 181-2009. (2009, de 14 de Diciembre). Ley General de Aguas. Diario Oficial La Gaceta No. 32, 088.

Ley No. 98-2007. (2008, de 26 de Febrero). Ley Forestal, Áreas Protegidas y Vida Silvestre. Diario Oficial La Gaceta No. 31, 544 .

International Energy Agency (IEA). Key World Energy Statistics 2012. Available in: <http://www.iea.org/publications/ freepublications/publication/kwes.pdf $>$. Accessed in: September 2013.

Statistics. 2013. Available in: < http://www.iea.org/ stats/index.asp $>$. Accessed in: September 2013.

Leff, Enrique. Political Ecology: A Latin America Perspective. Revista Desenvolvimento e Meio Ambiente, Curitiba: Editora UFPR, 27, 11-20, jan./jun. 2013.

Lima, V. 2011. Challenges for the Optimal Uses of Wind Power in Brazil. George Washington University. Available in: <http://www.aneel.gov.br/biblioteca/trabalhos/trabalhos/ Artigo_Vitor_Franca.pdf $>$.

Machado, C. J. S.; Vilani, R.; Chame, M. Public Policies for Sustainable Development in Brazil: the Role of Oil Royalties in the Institutionalization of a Policy of Preserving Biodiversity. Revista Desenvolvimento e Meio Ambiente, Curitiba: Editora UFPR, 25, 11-26, jan./jun. 2012.

Mexico. Secretaría de Energía - SENER. Estrategia Nacional para la Transición Energética y el Aprovechamiento Sustentable de la Energía. 2011.

. Secretaría de Energía - SENER. Sistema de información energética. Available in: <http://www.sener.gob.mx/portal/ Default.aspx?id=870>. Accessed in: July 2013.

Secretaría de Energía - SENER. Estrategia Nacional de Energía 2013-2027. Available in: <http://www.energia.gob. 
mx/res/PE_y_DT/pub/2013/ENE_2013-2027.pdf $>$. Accessed in: October 2013.

Molina, A. Nicaragua como anfitrión de Proyectos de Generación de Energía con Fuentes Renovables. Managua: Blog de Molina y Asociados Central Law. Nicaragua, 2012.

Moosavian, S et al. Energy policy to promote Photovoltaic generation. Renewable and Sustainable Energy Reviews, 25, 44-58, Sep. 2013. 15 p.

Nicaragua. Gobierno de Reconciliación y Unidad Nacional. Plan Nacional de Desarrollo Humano 2012-2016. Managua, 2012. p. 136-137.

. Instituto Nacional de Información de Desarrollo (INIDE). Anuario Estadístico 2010 - Estimaciones y Proyecciones de Población Revisión. 2012. Available in: <www.inide.gob. ni>. Accessed in: August 2013.

Instituto Nicaraguense de Energía. Capacidad Instalada en Nicaragua. 2012. Available in: $<\mathrm{http}$ ://www.elnuevodiario.com.ni/infografia/407>. Accessed in: August 2013.

. Ministerio de Energía y Minas. Ministerio de Energía y Minas expone cambio de matriz energética en Congreso Rio 2012. 2012. Available in: <http://www.mem.gob.ni/index. php?s=1\&idp=174\&idt=2\&id=444>. Accessed in: September 2013.

OLADE - Observatory of Renewable Energy - Nicaragua. 2012. Available in: <http://www.renenergyobservatory.org/ uploads/media/Nicaragua_Producto_1_y_2_Eng_.pdf $>$. Accessed in: September 2013 .

Radioamerica. Invierten 20 millones de dólares en primera etapa de planta de energía de biomasa en Honduras. 2012.
Available in: $<$ http://radioamericahn.net/inviertes-20-millones-en-primera-etapa-planta-de-energia-a-base-de-biomasa-en-honduras/>. Accessed in: July 2013.

Sánchez J. La crisis energética global, la posición de México en el mundo. 2011. Available in: <http://xivrem.ujaen.es/wp-content/uploads/2011/11/24-R-106M706.pdf $>$. Accessed in: August 2013.

Scott, C. A.; Pasqualetti, M. J. Energy and water resources scarcity: Critical infrastructure for growth and economic development in Arizona and Sonora. Natural Resources Journal, 50(3), 645-682, 2010.

Tribuna. Aquiriran prestamo por \$270 millones para terminar Patuca III. 2013. Available in: <http://www.latribuna. $\mathrm{hn} / 2013 / 07 / 09 /$ aprueban-suscripcion-de-convenio-para-conclusion-de-segunda-etapa-de-patuca-iii/ $>$. Accessed in August 2013.

Trucchi, G. 2010 Integracion Energetica Regional: el ejemplo de Nicaragua. Agencia Latinoamericana de Información. Available in: <http://alainet.org/active/41924>. Accessed in: August 2013.

United States of America. Carbon Dioxide Information Analysis Center (CDIAC). Fossil Fuel CO Emissions by Region Available in: $<$ http://cdiac.ornl.gov/trends/emis/meth_reg. html>. Accessed in: August 2013.

World Bank Indicators. Available in: $<$ http://data.worldbank. org/indicator $>$. Accessed in: August 2013.

Yamussa II, S.; Ansari, A.; Mustafa, M. Renewable Energy Development in Two Selected African Countries: An Overview and Assessment. Australian Journal of Basic \& Applied Sciences, 7(7), 867-873, Jul. 2013. 7 p. 